\title{
A Social Study of Coal mining Impacts on village society: With special reference to Bilaspur division in Chhattisgarh of India
}

\author{
Sunil Kumar ${ }^{1}$, Dr. Richa Yadav ${ }^{2}$ \\ ${ }^{1}$ Research Scholar (Social Work), Dr. C. V. Raman University, Kota, Bilaspur, Chhattisgarh, INDIA \\ ${ }^{2}$ Asst. Professor (Social Work), Dr. C. V. Raman University, Kota, Bilaspur, Chhattisgarh, INDIA
}

\begin{abstract}
In the state of Chhattisgarh, Ample opportunities are available for the production and development of coalrelated infrastructure and industrial establishments which create a conducive environment for the economic development of the state and the society. Coal is used as an important mineral resource in all countries, being the most reliable and cheap resource of all the non-renewable energy sources found on Earth so far.The industrial expansion of coal mining to a mineral-rich but economically backward country like India has not only helped the country fight against poverty but has also been a major factor in change and development in society. But the rapid mining activities have reduced the usefulness and benefits of natural resources of Chhattisgarhi rural and tribal society dependent on natural resources. Studies in related literature and articles show that coal mining, whether through opencast or underground mines, has been associated with various socio-economic changes such as land displacement, changes in social structure and changes in cultural lifestyles. In addition to human health and environmental problems such as air, water and noise, and pollution, it is also responsible for other problems such as decline in agricultural productivity, deforestation, loss in biological diversity.

In most of the cases, it has been seen that in the areas where coal projects are proposed for mining of the coal, the coal mining projects have to face heavy opposition from the local community. It is not that governance and administration do not try to protect and deal with the adverse environmental problems arising due to coal mining in the affected areas as well as to minimize the adverse effects of socio-economic changes of the affected community, the State Government and the Central Government have framed policies and Acts from time to time. But it also makes necessary amendments in it. However, so far the result is not satisfactory at the ground level. Coal industries also try to work in these areas and promise and claim the interests of stakeholders in mining affected areas but they also lag behind in social evaluation. The lack of expertise and policies to properly address the problems arising out of mining is clearly visible. Coal mining activities have a very negative impact on local biological diversity, especially where forest land is acquired for mining. It is globally accepted that coal mining adversely affects the local and global environment.
\end{abstract}

Key word - Coal mining, Social Change, Village Economic, Livelihood, Agriculture, Environment, DMF, CSR

\section{INTRODUCTION}

Since the industrial revolution of the 18th century, coal, one of the main sources of energy resources for the world, has remained an important mineral resource to meet the energy needs of all the developed and developing countries of the world. Almost all the developed and developing countries are increasingly dependent on mineral coal to meet their energy requirements. Coal is still being used as a major fossil fuel for energy production in developed countries such as America, England, Russia, Australia, China, and Japan. Coal is a fossil fuel of industrial and economic importance, which not only meets our industrial electric energy needs but also strengthens the economic system of the state and the country and opens the way for happiness, prosperity, and development for society. No doubt coal mining contributes a lot to the economic development of the nation. Coal is extracted by digging deep into the ground. The mining of coal is an industrial process that has a direct and indirect impact on human society and nature.

\section{BACKGROUND}

It has been an irony that most of the coal deposits are found under the ground of dense forests along the rivers. And these forests are rich in biological diversity. And around these thick forests and rivers, the tribal community and rural community live. It should be known that the tribal society resides in the villages and the tribal society in the forests and flourishes with the original traditions and beliefs in their native domicile areas and develops by establishing harmony with nature in course of the time. But when the forests of these areas are acquired for coal mining, in the process of this 
Vol. 8, Issue 8, August 2021

\section{DOI: 10.17148/IARJSET.2021.88107}

acquisition, the cultivated land of the village and the resident land of the villagers, and even their houses are often acquired. In such a situation, these natives have to bear the brunt of land displacement.

The phenomenon of displacement is the main reason for change and loss in social relations, cultural customs, and original traditions and beliefs in any society. And no society is easily prepared for this situation. In such rural areas of Chhattisgarh, where coal is already being mined on an industrial scale, the increasing production of coal in those areas results in increasing production and supply pressure. but also adversely affecting the health of the rural community of those rural areas. The effect of globalization, new inventions of information technology, and the expansion and application of the media have promoted more changes in the social and cultural aspects of the villagers of this affected area. Along with the social life of the rural and tribal communities of these mining-affected villages, many changes are seen in the cultural nature, economic aspect, and educational and health level.

\section{COAL PRODUCTION IN INDIA}

The coal is found in more than 50 countries in the world where it is produced. On looking at the list of top 10 coalproducing countries of the world, it is clearly visible that all these major coal-producing countries are counted in the group of developed and developing countries of the world today. According to the Global Energy Statistical Yearbook 2020 published, India has been ranked second among the top 10 coal-producing countries.

Production of coal in the top 10 countries of the world in the last five years (in million tons)

\begin{tabular}{|l|l|l|l|l|l|l|}
\hline \multirow{2}{*}{ S.No. } & Coal Producing & \multicolumn{5}{|l|}{ last five years coal production in the top 10 countries } \\
\cline { 3 - 7 } & Country & 2015 & 2016 & 2017 & 2018 & 2019 \\
\hline 1 & China & 3563 & 3268 & 3397 & 3550 & 3692 \\
\hline 2 & India & 683 & 703 & 725 & 771 & 745 \\
\hline 3 & United States & 814 & 661 & 703 & 686 & 640 \\
\hline 4 & Indonesia & 455 & 463 & 495 & 591 & 585 \\
\hline 5 & Australia & 512 & 500 & 499 & 496 & 500 \\
\hline 6 & Russia & 353 & 368 & 389 & 421 & 425 \\
\hline 7 & South Africa & 255 & 255 & 257 & 259 & 264 \\
\hline 8 & Germany & 185 & 176 & 175 & 170 & 132 \\
\hline 9 & Kazakhstan & 107 & 103 & 113 & 119 & 117 \\
\hline 10 & Poland & 136 & 131 & 127 & 122 & 112 \\
\hline
\end{tabular}

source:-https://yearbook enerdata.net/total-energy/world-energy-production.html

As a fossil fuel, India has a fifth place in the world in terms of coal reserves, while in terms of production, India definitely holds second place after China, but our country is far behind China in terms of coal production capacity. At present, in the amount of coal that our country is producing, we are unable to supply coal according to our domestic energy demand. This is the reason that our country has to import coal from countries like Australia and Indonesia to meet the current energy requirement of the country.

STATE WISE COAL RESERVES AND PRODUCTIONIN INDIA

According to Geological Survey of the India, almost 326.4495 billion tons of coal reserves have been estimated in India as on 01.04.2019 based on the resources projected by CMPDL, MECL, GSL, SCCL and some private and public entrepreneurs of India.

state wise coal reserves in India as dated on 01.04.2019 as follows

\begin{tabular}{|l|l|l|}
\hline STATE NAME & $\begin{array}{l}\text { STATE } \\
\text { RESERVES } \\
\text { IN TONS }\end{array}$ & $\begin{array}{l}\text { STATE } \\
\text { RESERVES } \\
\text { IN \% }\end{array}$ \\
\hline JHARKHAND & 84.506 & 25.88 \\
\hline ODISHA & 80.84 & 24.76 \\
\hline CHHATTISGARH & 59.908 & 18.35 \\
\hline WEST BENGAL & 31.69 & 9.71 \\
\hline M.P. & 28.793 & 8.82 \\
\hline
\end{tabular}


Vol. 8, Issue 8, August 2021

DOI: 10.17148/IARJSET.2021.88107

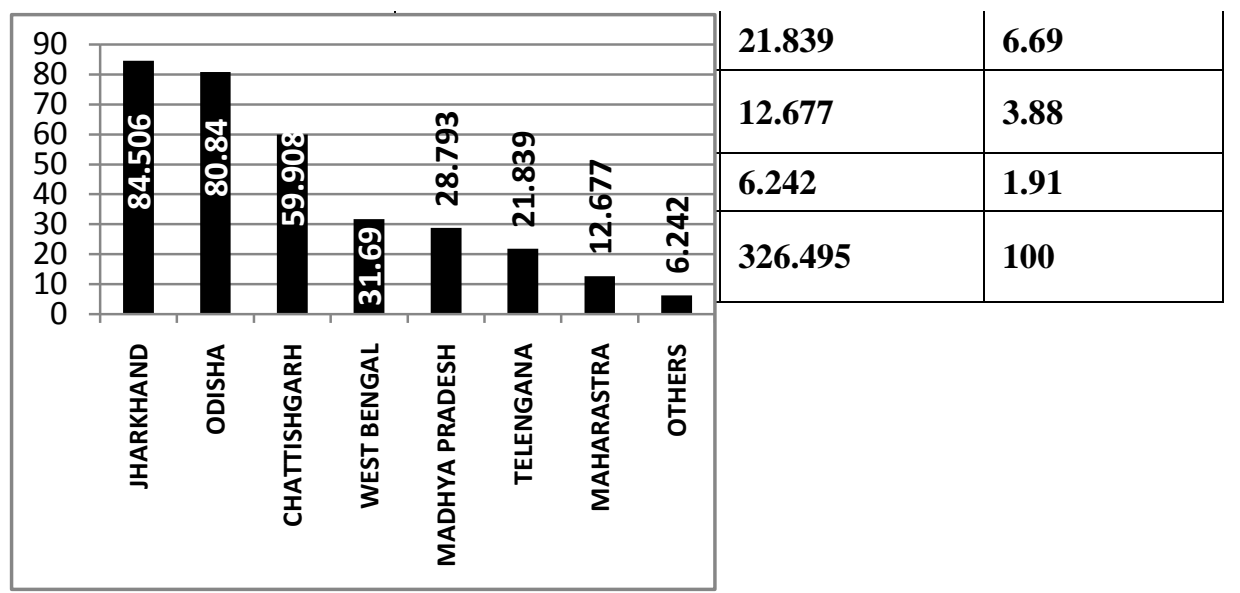

\section{COAL RESERVES AND PRODUCTION IN CHHATTISGARH}

In Chhattisgarh, coal minerals are obtained from the rocks of the Gondwana rock group and a bituminous type of coal is found here. Coal mining in Chhattisgarh started only in the 60s. Coal is produced in the district Koriya, Surajpur, Surguja, Balrampur, Korba, and Raigarh in the state. All these districts are located in the northeastern part of Chhattisgarh. Coal is contributing 48.11 percent to the mineral revenue of the state. The state has present reserves of $\mathbf{5 9 . 9 0 8}$ million tons of coal, which is 18.35 percent of the nation's coal reserves. The share of Chhattisgarh in the coal production of the nation is 21.01 percent. At present, Chhattisgarh ranks first among coal-producing states. Coal produced in the state is being used in cement and steel industries besides national and state-level electric thermal plants.

\section{THE OBJECTIVES OF RESEARCH:-}

Present research work "Coal mining and rural community: Study of social development (with special reference to

Bilaspur division of Chhattisgarh)" In the above-described socio-economic change and development of rural community affected by coal mining, exploratory analysis. To conduct the analytical research study. Mining work at the industrial level of coal in Bilaspur division and rapid expansion of coal mines has affected the natural environment and

social environment of the affected area on many levels and aspects. As a result, many socio-economic and cultural changes are taking place in the rural society of Chhattisgarh, for which it is necessary to study them scientifically over a period of time to understand them properly.

The main objectives of research in the present study were as follows:

- To study the changes in socio-economic and cultural composition of coal mining affected rural areas in Bilaspur division of Chhattisgarh.

- $\quad$ To study the role of various government and non-governmental organizations towards the change and advancement in the socio-cultural and economic system as well as livelihood structure of the coal mining affected rural community.

- Social assessment of the impacts of the works done under the Corporate Social Responsibility (CSR) policy of the coal mining industry on the social life of the affected rural community in the areas.

- $\quad$ To study the impacts of the Industrial Policy and Mines and Mineral Policy of the Government of Chhattisgarh in the transformation and development of the socio-economic and cultural structure of rural areas affected by coal mining.

\section{STUDY AREA ANDRESEARCH METHODOLGY}

This research was focused on the rural community of coal-producing district Raigarh and Korba, of Chhattisgarh's Bilaspur division affected by coal mining. Beacause coal is mined only in Raigarh and Korba districts in Bilaspur division, therefore, in this research study, coal mining affected villages of these two districts of Bilaspur division have been studied. 15 affected villages of Korba district and 10 affected villages from Raigarh district were selected by the Non-Probability Sampling. Thus, a total 25 highly affected villages from RaigarhandKorba districts have been selected for the study as a sample villages for the research. In each of the selected villages, 20 families were selected for the questionnaire on the basis of the social, caste structure, and hierarchical order of the families. In this way, data has been collected through questionnaires from a total of 500 families from both districts. Multilevel sampling has also been used in this process. 


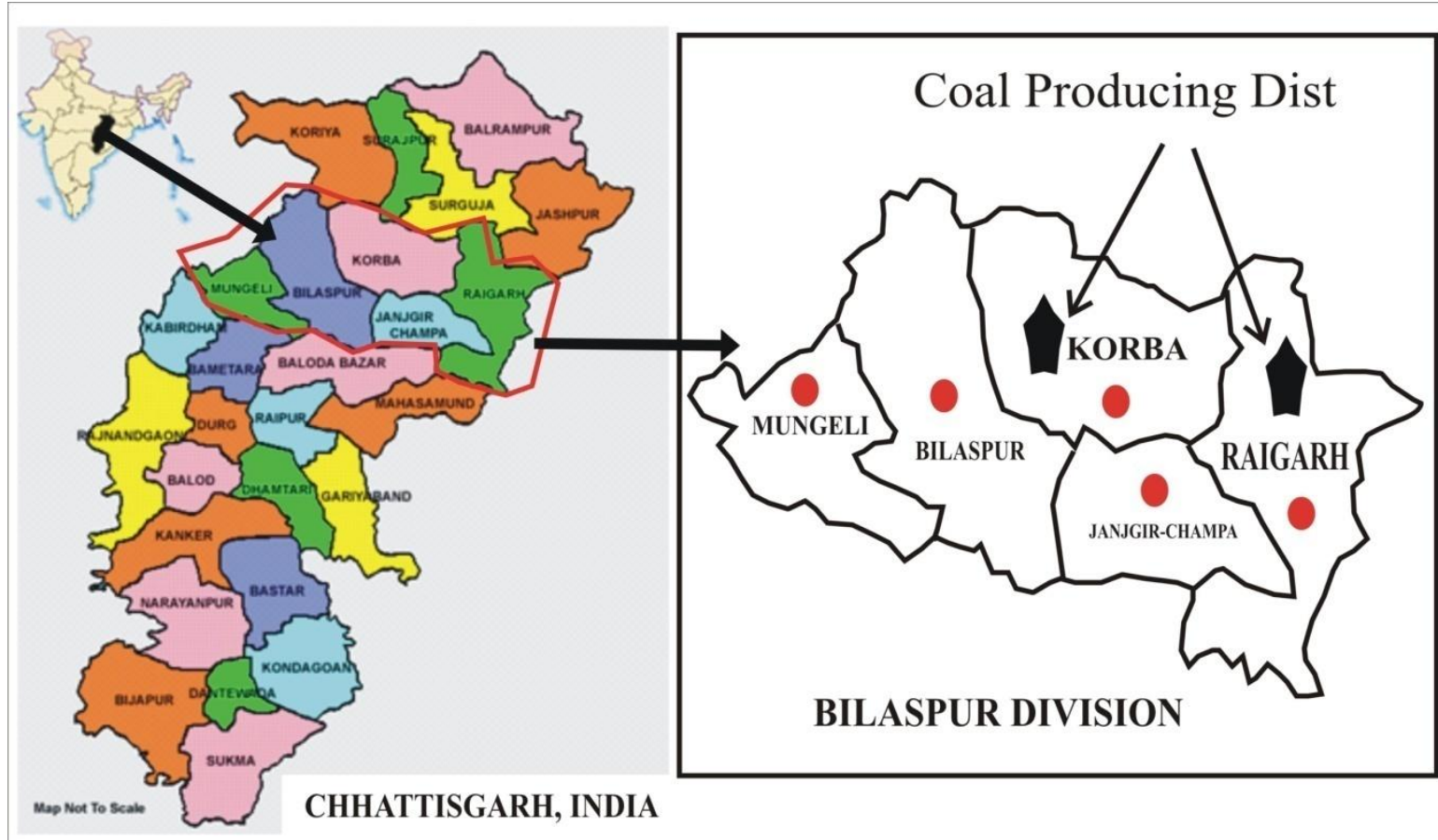

No. of Coal Mining Affected Villages and Households Selected as Study Sample of Bilaspur Division of C.G.

\begin{tabular}{|l|l|l|l|l|l|}
\hline S.No & $\begin{array}{l}\text { DistunderBilspurDiv } \\
\text { of Chhattisgarh }\end{array}$ & $\begin{array}{l}\text { Coal } \\
\text { producing } \\
\text { District }\end{array}$ & $\begin{array}{l}\text { No. of Active } \\
\text { Coal Mines }\end{array}$ & $\begin{array}{l}\text { No of selected } \\
\text { Villages as the } \\
\text { study samples }\end{array}$ & $\begin{array}{l}\text { selected No of } \\
\text { House holds }\end{array}$ \\
\hline 1 & Bilaspur & & & & $15 \times 20=300$ \\
\hline 2 & Korba & Korba & 16 & 15 & $10 \times 20=200$ \\
\hline 3 & Mungeli & Raigarh & 10 & 10 & \\
\hline 4 & Raigarh & & & & \\
\hline 5 & Janjgir-Champa & & & $\mathbf{5 0 0}$ \\
\hline 6 & $\begin{array}{l}\text { Gaurella-Pendra- } \\
\text { Marwahi }\end{array}$ & & & \\
\hline & $\begin{array}{l}\text { Total number of villages and households selected as } \\
\text { sample }\end{array}$ & $\mathbf{2 5}$ & \\
\hline
\end{tabular}

\section{COLLECTION OF DATA}

This study has been done at ground level in the coal-producing districts of Korba and Raigarh of Bilaspur division in Chhattisgarh. The data collectionsis based on intensive field visits and field surveys in both districts, apart from a qualitative micro-level study aimed at understanding the impacts of coal mining in selected villages. Data were collected from both primary and secondary sources to meet the focused objectives of the study. For primary data collection, in addition to quantitative techniques, qualitative sociological and anthropological tools have been used in this study. As part of qualitative data collection, techniques such as survey and observation, both participant and nonparticipant, case studies, interviews, formal and informal interviews, and group discussions focused on some Project Affected People (PAP) were used. The household survey was conducted using a pre-structured questionnaire to collect quantitative data.

\section{PRIMARY DATA}

Under the primary source of the data, the method of observation, sampling, and interview and interview schedule method has been used, through which the facts related to the study subject were attached by selecting the respondents 


\section{DOI: 10.17148/IARJSET.2021.88107}

and through a structured questionnaire, face-to-face, and group interview. Facts and data were collected from the related subject. The study has been conducted using a systematic random sampling method

\section{SECONDARY DATA}

In addition to the primary source, the secondary sources include government documents, statistics, census, magazines, newspapers, published books related to mining and industries and industrialization, publications related to research work and research, magazines, reports, and related contents-materials available on the Internet, etc.

\section{METHODS OF DATA ANALYSIS}

Based on the specific objectives of the research study, the collected data, both qualitative and quantitative, have been analyzed. The collected quantitative data has been tabulated and statistically analyzed by computing the mean, standard deviation, percentage, and frequency with the help of Microsoft Office software. Similarly, gathered qualitative data has been explained on the basis of information from the field using tools such as case studies, interviews and observation techniques.

Based on the objectives of the research study, the four major impacts that have been focused, these are:- First, the study of changes in the socio-cultural structure and economic system. second, the impact on agriculture-livelihood and environment. third, social assessment of works done under Corporate Social Responsibility by considering of the interests of the affected people and village and fourth the study of the mining policy of the coal industries and the Mines and Mineral Policy of the Government of Chhattisgarh. While analyzing the data, gender, age, education, community, caste, distance from the active mining area, means of livelihood, social assessment of mining industries' CSR works, and community development works carried out by the Government of Chhattisgarh under mineral trust, the role of local authorities like Gram Panchayat and Nagar Palika Parishad were considered.

\section{FINDINGS AND DISCUSSION}

The contribution and efforts of the state in the overall social development of any state remains unparalleled. A similar fact about C.G. is equally applicable to all the communities and society of the state. Coal mining projects increase economic investment in the state in many ways, which is important in the economic development of the state. but the socio-cultural lifestyle of the coal mining projects affected rural communities has a very negative impacts. At the economic level, they become strong, but in this, also inequalities are high. coal mining has far-reaching negative effects on the environment and health. For these reasons, the state government pays special attention to the development of villages affected by mining and industrialization of coal and other minerals. Mining industrial units also try to fulfill their responsibility under Corporate Social Responsibility (BAT), and for the development of these affected areas, apart from promoting various schemes and projects. they also run various social development programs which are indirectly or directly help in the development of affected communities and the area.

\section{LAND DISPLACEMENT}

Generally, social and economic development in rural society is slower than in urban society. But social change and development takes place at a very rapid pace in the mining-affected rural community. As soon as the processes of industrial mining start in a rural area, changes start in the social structure, cultural customs and economic system of the rural society of that area. It is a universal truth about coal mining that the local citizens of the area where coal is mined have to face involuntary social problems like land displacement. Therefore, land displacement as a major and primary social problem arises first in the mining affected rural community. Which is often socially opposed by the rural community.

\section{Change in the social composition of the local population}

The most important factor in the social structure is the size and composition of the population of the affected community. In the direction of social and economic change that started with land acquisition, In the process of mining, starts increasing in the size and composition of the population. The increase in the population in the form of migrant laborers and industrial workers from outside in the local village has led to a change in the caste structure of the population. Most mining companies build housing colonies for their regular employees in local areas, which creates a parallel colony existence as a residential colony nearby village in the local area.

\section{Changes in the economic system and livelihood patterns}

With the change in the social aspect, the economic status of the affected rural community also improves. But where the change in the social side is generally equally effective, the same cannot be said about the economic side. Economic 
International Advanced Research Journal in Science, Engineering and Technology

Vol. 8, Issue 8, August 2021

DOI: 10.17148/IARJSET.2021.88107

inequalities are seen in most of the coal mining-affected rural communities. The Pattern of Rural livelihoods have been changed after coal mining activities

Income-group-wise sources of income of the families surveyed

\begin{tabular}{|l|l|l|l|l|}
\hline \multirow{5}{*}{ S.N } & Income group & \multicolumn{2}{|l|}{ Families } & \multirow{2}{*}{ Income source of families } \\
\cline { 2 - 5 } & No & Per \% & Barber, washer-man, Landless Labor\& Others \\
\hline 1 & 6,000 & 10 & 2 & $\begin{array}{l}\text { Agriculture and animal husbandry or vegetable } \\
\text { cultivation }\end{array}$ \\
\hline 3 & $6,000>10,000$ & 28 & 5.60 & agriculture and construction \\
\hline 4 & $15,000>20,000$ & 40 & 8 & $\begin{array}{l}\text { Auto Mechanic, Electronics Sales \& Repair \& Other } \\
\text { Service Sectors }\end{array}$ \\
\hline 5 & $20,000>25,000$ & 120 & 24 & $\begin{array}{l}\text { Agriculture with Auto Mechanic, Electronics Sales } \\
\text { \& Repair and other service sectors }\end{array}$ \\
\hline 6 & $25,000>30,000$ & 20 & 4 & small or private institutes job \\
\hline 7 & $30,000>35,000$ & 40 & 8 & Jobs in Coal Mines (PT) and Agriculture \\
\hline 8 & 35,000 and more & 182 & 36.40 & Jobs in coal mines or other big institutions \\
\hline & $\begin{array}{l}\text { Total surveyed } \\
\text { Families }\end{array}$ & 500 & $100 \%$ & \\
\hline
\end{tabular}

\section{SYSTEM}

The caste system was more dominant in these villages before mining. The role of each caste group was strictly defined and functioned in the society according to the rules of their caste-based occupational restrictions. With the introduction of mining, the change in the agrarian economy and the change in the size and caste structure of the rural population, along with the improvement in the level of education and awareness of constitutional rights weakened the caste system. Although the caste system is not particularly dominant in rural society individually, it is still in practice and makes its presence felt socially in cultural events and rituals rights in the studied village.

\section{GOVT. AND MINING INDUSTRIES POLICIES FOR MINING-AFFECTED PEOPLE}

Coal mining projects increase economic investment in the state in many ways, which is important in the economic development of the state. For this reason, the state government pays special attention to the development of villages and communities affected by mining activities. Mining industrial units also try to fulfill their responsibility under Corporate Social Responsibility (CSR), and for the development of these affected areas, besides promoting various schemes and projects, various social development programs also run, which are indirect. It helps in the development of that area. Govt.also has established District Mineral Foundation (DMF) as a non-profit trust body in all thedistricts of Chhattisgarh, which works for the benefits and profit of the individuals, families and areas affected by mining related activities.DMF is funded through contribution from mine Industries. In this study, in selected villages, On the question of social evaluation of community infrastructure being constructed by mining companies under CSR head, and Govt. efforts for the mining affected area and people, only 50\% of the selected respondents have expressed their satisfaction and $90 \%$ Selected respondents believe that mining companies need to do more work on basic infrastructure like health, education and environment in the affected rural area.

\section{CONCLUSION}

From the analysis of the facts and data obtained from this research study, it can be concluded that the coal mining activities have provided very favorable conditions for the economic development of the coal mining affected villagers to the community of the affected area. In these coal mining affected areas, along with new resources of employment, many business opportunities have also increased. But this stream of development has also brought significant sociocultural, environmental and health issues to the affected communities. Especially, especially, it has adversely affected the agricultural, social structure, environment and human health aspect of the dwellers of the coal mining affected area.Today there is a need to work on the policy of "clean coal" for the better health of the affected community and to 


\section{International Advanced Research Journal in Science, Engineering and Technology}

Vol. 8, Issue 8, August 2021

DOI: 10.17148/IARJSET.2021.88107

improve the quality of the environment. Although there is no concrete alternative solution for mining operations yet, alternatives to location and modern mining techniques can actually reduce the damage to the environment.All types of CSR activities should be done with the participation of the affected communities (with the consent and approval of the Gram Panchayat). Before implementing of CSR and DMF activities in the affected areas, discussions should be held with the affected people so that the works being done under the CSR and the DMF can be properly utilized for affected communities. The land acquired for mining of coal should be provisioned for reclamation and reuse of the land after the mining is over. Adequate power and space should be given to the Gram Panchayat Sabha in the District Mineral Foundation by empowering the Gram Panchayat and other authorized Local bodies.

\section{REFERENCES}

1. Dr. Mishra, Niharranjan (Project Director),(2015) Research Study on Coal Mining, Displacement and Rural Livelihoods: A Study in Mahanadi Coalfield Odisha, Department of Humanities and Social Sciences, National Institute of Technology (NIT) Rourkela, Odisha, India

2. Das, Nabnita, (August 2015), Socio-economic Impact of Mining on Rural Communities: A Study of the Ib Valley Coalfield in Odisha, DEPARTMENT OF HUMANITIES \& SOCIAL SCIENCES NATIONAL INSTITUTE OF TECHNOLOGY ROURKELA, ODISHA, INDIA

3. Dr. Dubey, Kumud, (Project Director)(2017), Socio Economic Impact Study of Mining and Mining Polices on the Livelihoods of Local Population in the Vindhyan Region of Uttar Pradesh, Center for Social Forestry and Eco-Rehabilitation, (Indian Council of Forestry Research and Education, Dehradun).

4. Surendra Babu, Akkala, (May, 2016), ANALYSIS OF IMPACT OF CORPORATE SOCIAL RESPONSIBILITY INITIATIVES OF INDIAN COAL MINING INDUSTRY ON SOCIETY - WITH SPECIAL REFERENCE TO KORBA COALFIELDS OF CHHATTISGARH (INDIA), ICFAI UNIVERSITY JHARKHAND, RANCHI.

5. Ms. Ritu; Preeti Chawla. "Indian Environment for Entrepreneurship: A Study based on Literature Review". International Research Journal on Advanced Science Hub, 3, Special Issue ICIES-2021 4S, 2021, 18-21. doi: 10.47392/irjash.2021.104

6. Ms. Shivani. "Work from Home and applicability of the same on Education Sector: With Reference to Private Universities in Himachal Pradesh". International Research Journal on Advanced Science Hub, 2, Special Issue ICSTM 12S, 2020, 39-43. doi: 10.47392/irjash.2020.258

7. Anupam Verma; Vandana Srivastava. "Natural Resource Consumption and Lockdown". International Research Journal on Advanced Science Hub, 2, 6, 2020, 79-86. doi: 10.47392/irjash.2020.41

8. http://shodhganga.inflibnet.ac.in

9. http://nmdc.nic.in

10. http://www.dmf.cg.nic.in

11. http://chhattisgarhmines.gov.in

12. http://www.mines.nic.in

13. http://www.coalindia.in

14. www.researchgate.net

15. www.coal.nic.in 